\title{
Allmennlegenes tid til pasientarbeid i ulike land
}

Tiden brukt på direkte pasientarbeid har innvirkning på behandlingskvaliteten.

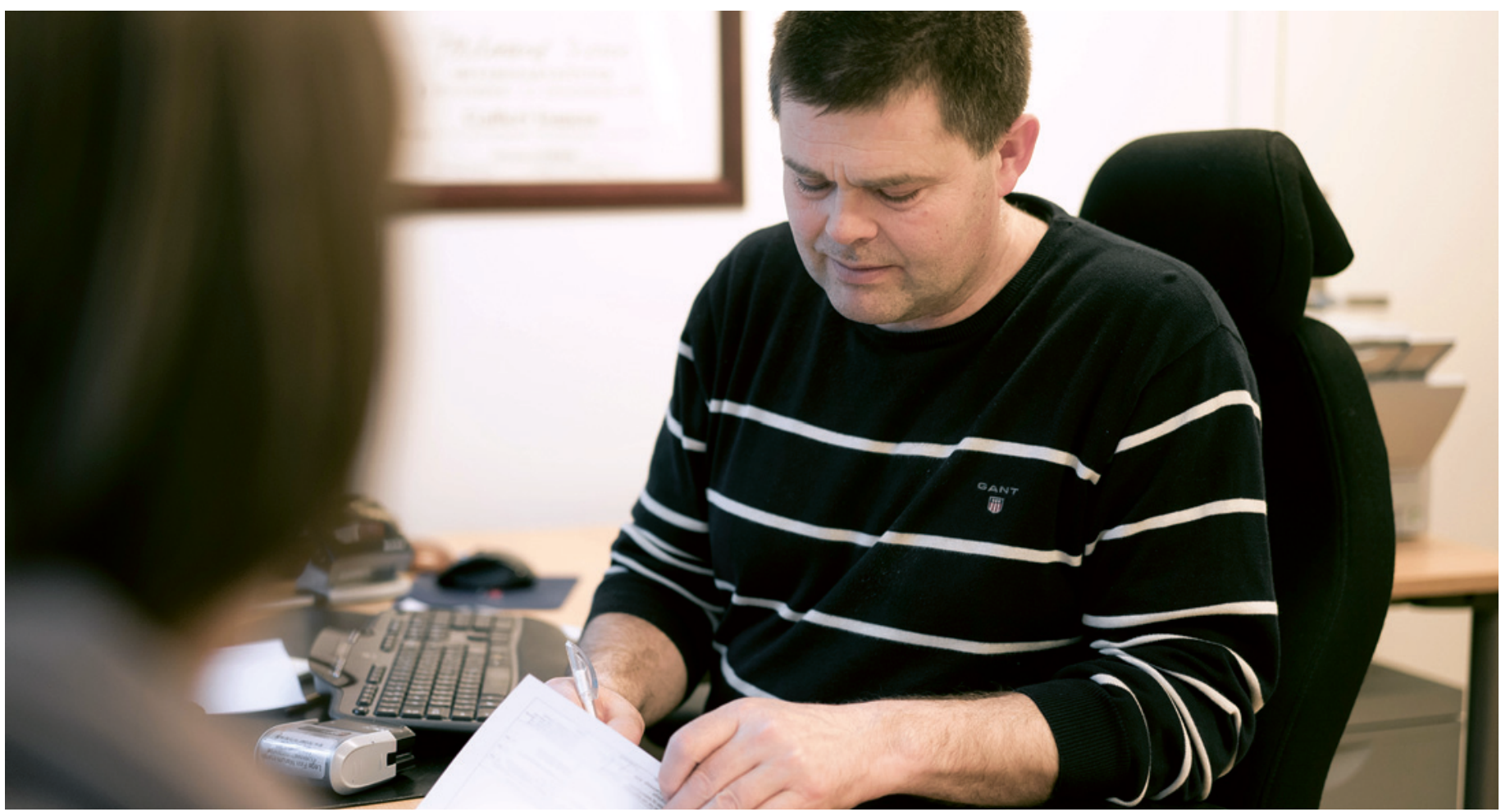

Illustrasjonsfoto: Ole Kristian Losvik

Flere studier tyder på at tid brukt til direkte pasientarbeid har positiv innvirkning på behandlingskvaliteten og gir mer fornøyde pasienter og leger (1). Man kan spørre seg om det finnes en optimal tidsbruk for kontakt mellom pasienter og leger i allmennpraksis.

Commonwealth Fund gjennomfører årlige helsetjenesteevalueringer i en rekke land. I 2015 ble allmennleger fra ti land blant annet spurt om omfanget av pasientrettet arbeid. Undersøkelsen viser at andelen total ukearbeidstid brukt på ansikt-til-ansikt-kontakt med pasienter varierer - den er $70 \%$ i Norge, Storbritannia, Tyskland, New Zealand og Sveits, $85 \%$ i Australia, $80 \%$ i Canada og USA og $60 \%$ i Nederland og Sverige (2). Dette er i tråd med en studie basert på data fra Legepanelet, der vi så på utviklingen i legers arbeidstid og tiden brukt på direkte pasientarbeid i perioden 1994-2014. For allmennleger og fastleger som jobber heltid, var den samlede ukearbeidstiden stabil og andelen direkte pasientarbeid var marginalt endret fra $73 \%$ til $69 \%$ i dette tidsrommet (3).

Lengden på konsultasjonene viste også variasjoner landene imellom. Allmenn- legene i Norge, Sverige og Sveits brukte gjennomsnittlig 20 minutter per konsultasjon, mot 17 minutter i USA, 15 minutter i Australia, Canada og New Zealand og ti minutter i Tyskland, Nederland og Storbritannia. Andelen allmennleger som var fornøyde eller svært fornøyde med tiden de bruker på hver pasient varierte fra $75 \%$ i Australia til $26 \%$ i Storbritannia. Andelen for norske leger var $67 \%$ (2).

Selv om det i Norge ikke var noen endring $i$ ansikt-til-ansikt-tid eller konsultasjonstid fra 2012 til 2015 økte andelen allmennleger som var fornøyde eller svært fornøyde med tiden de har til hver pasient fra $63 \%$ til $67 \%(2,4)$.

En fersk publikasjon fra Cochrane Database of Systematic Reviews konkluderer med at konsultasjonstidens lengde ikke nødvendigvis har betydning for pasientens tilfredshet med behandlingen, antall henvisninger eller antall forskrevne medisiner (5). En annen systematisk litteraturoversikt viser at det ikke er lengden av konsultasjonen i seg selv, men innholdet som påvirker pasienttilfredsheten (6).

God pasientbehandling er avhengig av både individuelle og organisatoriske faktorer. Disse studiene viser at måling av direkte ansikt-til-ansikt-tid ikke er tilstrekkelig for å fullt ut forklare verken legers eller pasienters tilfredshet med konsultasjonen. Vi trenger å komplettere med mål som også kan si noe om innholdet i konsultasjonen.

\section{Judith Rosta}

LEFO - Legeforskningsinstituttet

\section{Litteratur}

1. Dugdale DC, Epstein R, Pantilat SZ. Time and the patient-physician relationship. J Gen Intern Med 1999; 14 (suppl 1): S34-40.

2. Steiro A, Haugum M, Sjetne IS et al. Commonwealth Fund-undersøkelse blant allmennleger it land: norske resultater i 2015 og utvikling over tid. Rapport fra Kunnskapssenteret nr. 26, 2015. Oslo: Kunnskapssenteret, 2015

3. Rosta J, Aasland OG. Legers arbeidstid og tid til pasientarbeid i perioden 1994-2014. Tidsskr Nor Legeforen 2016; 136: 1355-9.

4. Haugum M, Bjertnæs $\emptyset \mathrm{A}$, Iversen $\mathrm{HH}$ et al. Commonwealth Fund-undersøkelse blant allmennleger i 10 land: norske resultater i 2012 og utvikling siden 2009. Rapport fra Kunnskapssenteret nr. 11, 2012. Oslo: Kunnskapssenteret, 2012.

5. Wilson AD, Childs S, Gonçalves-Bradley DC et al. Interventions to increase or decrease the length of primary care physicians' consultation. Cochrane Database Syst Rev 2016; 8: CD003540.

6. Lemon TI, Smith RH. Consultation Content not Consultation Length Improves Patient Satisfac tion. J Family Med Prim Care 2014: 3: 333-9. 